\title{
Effects of a "New" Human Respiratory Virus in Volunteers
}

\author{
A. F. BRADBURNE,* B.SC. ; M. L. BYNOE,* M.B., D.T.M.\&H., D.OBST.R.C.o.G. \\ D. A. J. TYRRELL,* M.D., F.R.C.P., M.C.PATH.
}

Brit. med. J., 1967, 3, 767-769

We recently reported the cultivation in organ cultures of a virus, B814, which caused colds in volunteers but could not be detected or propagated in tissue cultures (Tyrrell and Bynoe, 1965). Hamre and Procknow (1966) have discovered a " new" virus in the respiratory tract of six students suffering from colds. There was a slight viral cytopathic effect in tissue cultures of human embryo kidney cells, but the virus was subsequently adapted to the WI-38 strain of human embryo fibroblasts. Both of these viruses were ether-labile but apparently unrelated serologically to any known myxoviruses. It now appears that they are morphologically identical and indistinguishable from the viruses of avian infectious bronchitis (Almeida and Tyrrell, 1967), and mouse hepatitis (Tyrrell and Almeida, 1967). The particles are $80-120 \mathrm{~m} \mu$ in diameter, pleomorphic, and surrounded by a fringe of club-shaped projections about $20 \mathrm{~m} \mu$ in length. Recently, further viruses of this morphological type have been isolated in organ cultures by McIntosh et al. (1967).

We have now given the prototype strain, 229-E, of Hamre and Procknow to volunteers in order to determine whether it causes colds and to study serum neutralizing antibody during infections with viruses of this type.

\section{Materials and Methods}

Virus.-The 229-E virus was received from Dr. Hamre as tissue culture fluid. It was then passed in human embryonic lung fibroblasts and in organ cultures of human embryo trachea. This material was not apparently contaminated with bacteria or other viruses and was inoculated into volunteers, in whom it was passed further. For the inoculation of volunteers organ culture fluids or nasal washings were diluted 1 in 10 in saline and $0.5 \mathrm{ml}$. was dropped into each nostril.

Tissue Cultures.-Locally propagated strains of human embryo lung fibroblasts were used. They were cultivated by the methods of Hayflick and Moorhead (1961) and maintained in a roller drum at $33^{\circ} \mathrm{C}$. in a medium containing $2 \%$ ox serum and $98 \%$ Eagle's medium (Gibco: G13) with penicillin, streptomycin, and achromycin.

Organ Cultures.-These were maintained by a modification (Tyrrell and Blamire, 1967) of the original method of Hoorn (1966) with $1.25 \mathrm{ml}$. of Eagle's medium containing $0.2 \%$ bovine plasma albumin in an atmosphere of $5 \% \mathrm{CO}_{2}$ in air, at $33^{\circ} \mathrm{C}$.

Virus Isolation.-Nasal washings were collected with about $10 \mathrm{ml}$. of sterile saline, mixed with an equal volume of nutrient broth, and stored at $-70^{\circ} \mathrm{C}$. Two or three cultures of fibroblasts were inoculated with $0.2 \mathrm{ml}$. of nasal washings and changed six hours later. A widespread cytopathic effect appeared within four days of inoculation in the case of positive isolation. All isolated viruses were identified by neutralization with a specific antiserum produced in guinea-pigs and provided by Dr. Hamre.

Neutralization Tests.-Serial dilutions of inactivated serum were mixed with equal volumes of virus, held at room temperature for two hours, and $0.2 \mathrm{ml}$. of the mixture was inoculated into each of two or three cultures. The test was read about

\footnotetext{
- From the Common Cold Research Unit, Salisbury, Wilts.
}

six days later. Complete neutralization of the virus was taken as the end-point. It was found essential to use small doses of virus in order to detect antibody, and in tests reported here between 25 and $100 \mathrm{TCD}_{50}$ were employed. In the serological survey all sera were tested at a dilution of 1 in 10 . A number of preparations of 229-E virus fixed complement with volunteers' sera. However, no rising titres were detected in the sera from infected volunteers ; it is therefore not certain that the fixation was specific, and consequently the results are not reported here.

Volunteers.-These were of both sexes, aged 18 to 50 years, and were cared for in isolation as described elsewhere (Andrewes, 1948 ; Tyrrell, 1965).

Sera were collected before inoculation and two to three weeks later, and nasal washings were collected daily for five days after inoculation.

\section{Results}

As a preliminary to volunteer inoculation we wished to know whether specific antibodies against the virus $229-\mathrm{E}$ were present in the sera of inhabitants of Britain. Accordingly sera collected over the past 10 years from subjects living in various areas were tested at a dilution of 1 in 10 in the neutralization test. As can be seen from Table I, about $30 \%$ of sera neutralized the virus.

TABLB I.-Presence of Neutralizing Antibody in Human Sera

\begin{tabular}{c|c|c|c}
\hline \multirow{2}{*}{$\begin{array}{c}\text { Age Group } \\
\text { (years) }\end{array}$} & \multicolumn{2}{|c|}{ No. of Sera } & $\begin{array}{c}\text { Percentage } \\
\text { Positive }\end{array}$ \\
\cline { 2 - 4 } & Tested & Positive & \\
\hline $0-5$ & 32 & 8 & 25 \\
$6-10$ & 23 & 5 & 23 \\
$11-15$ & 39 & 10 & 20 \\
$16-20$ & 40 & 32 & 41 \\
$21-50$ & 81 & 63 & 29 \\
\hline Total & 215 & & \\
\hline
\end{tabular}

The adult sera were collected from volunteers arriving at the Unit over the pas 10 years. The minors' sera were taken from hospital patients in Liverpool and Sheffield.

About $40 \%$ of adults possessed antibody, and though the incidence was lower in children it seemed that they also were being infected by this or an antigenically related virus even within the first five years of life.

\section{Passage of Virus in Volunteers}

The passage history of the virus is summarized in Fig. 1. This shows that after a total of seven passages in tissue cultures in the U.S.A. and here it multiplied freely in human tracheal epithelium. However, the cilia continued to beat for eight days and sections of the cultures showed little abnormality. Organ culture fluid apparently produced a cold in four out of six volunteers. Nasal washings were collected from a volunteer who developed a cold and excreted virus, and these were passed to more volunteers. At each of a total of four serial passages in volunteers, colds were produced. Virus was recovered in tissue culture, and the dose of virus in the diluted nasal secretion used for each passage is shown on the left of the diagram. 
Twenty volunteers were given saline in parallel with these experiments and none developed colds. There is therefore no doubt that the virus did multiply in the human respiratory tract and apparently caused colds.

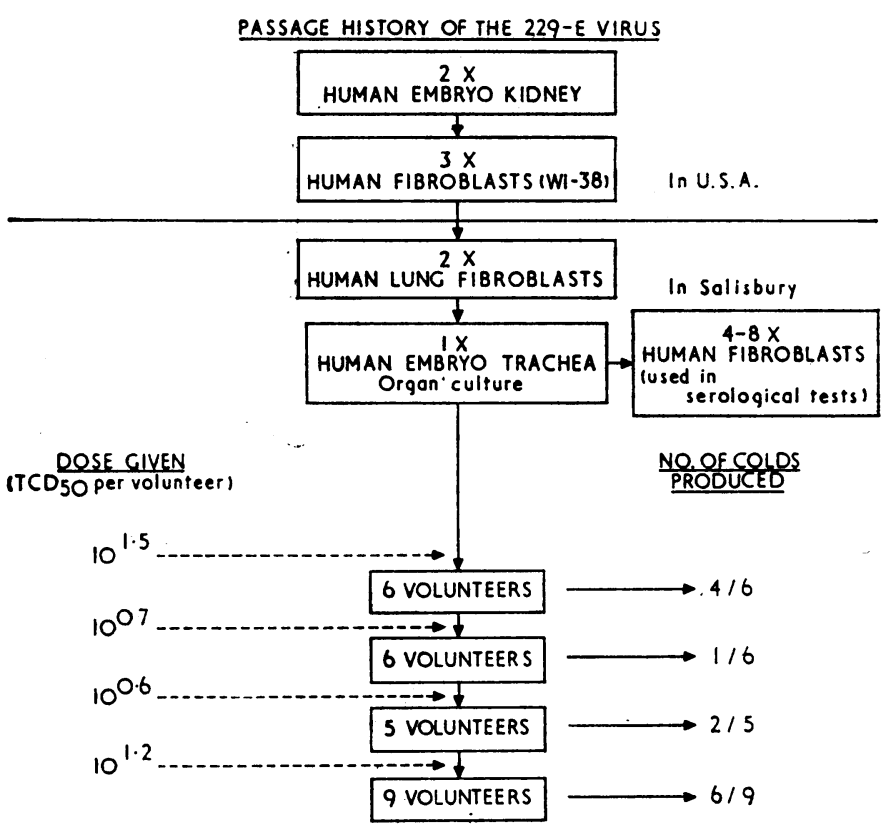

FIG. 1.-Passage history of the 229-E virus.

Table II shows that half the inoculated volunteers developed colds ; virus was recovered from all of these subjects but from only about one-third of those who remained well, and this difference is highly significant statistically. Nevertheless, the frequency of virus excretion varied a great deal from individual to individual, even when small doses of virus derived from man were given; this can be seen from Table III, the amount and

\begin{tabular}{|c|c|c|c|c|}
\hline \multirow{2}{*}{ Type of Volunteer } & & \multicolumn{3}{|c|}{ Results of Virus Isolation Tests } \\
\hline & & Positive & Negative & Total \\
\hline 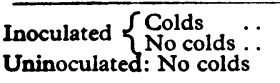 & $\begin{array}{l}\cdots \\
\cdots\end{array}$ & $\begin{array}{r}13 \\
5 \\
0\end{array}$ & $\begin{array}{l}0 \\
8 \\
6\end{array}$ & $\begin{array}{r}13 \\
13 \\
6\end{array}$ \\
\hline Total & $\cdots$ & 18 & 14 & 32 \\
\hline
\end{tabular}

For the upper two rows of this table $0.01>P>0.001$

TABLE III.-Pattern of Virus Excretion in 14 Infected Volunteers in the Second to Fourth Passage Experiments

\begin{tabular}{l|l|l|l|l} 
& \multicolumn{3}{|c|}{ Duration of Virus Excretion (days) } \\
\hline & 1 & 2 & 3 & 4 \\
\hline $\begin{array}{l}\text { No. of volunteers who excreted virus } \\
\text { for indicated number of days }\end{array}$ & 3 & 1 & 4 & 4 \\
$\begin{array}{l}\text { No. of above volunteers who developed } \\
\text { colds ... }\end{array} \quad$.. & 2 & 1 & 2 & 3 \\
\hline
\end{tabular}

period of virus excretion not apparently being related to the occurrence of colds. Only one volunteer excreted virus on the day after inoculation, and the frequency of virus excretion was at its peak at about the same time as the peak of clinical symptoms, as can be seen from Fig. 2. The titre of virus in 10 positive nasal washings ranged from $10^{0.5}$ to $10^{2.5}$ with a geometric mean of $10^{1.5}$.

\section{Serological Response to Infection}

Neutralization tests were performed on the sera from all the inoculated volunteers and from four volunteers who were given saline (Table IV).
The only significant titre rises-that is, of fourfold or greater -were found in 7 of the 13 volunteers who developed colds. Colds occurred in both those with and without antibody at the time of inoculation, but antibody rises were found mainly among those with a titre of 5 or less.
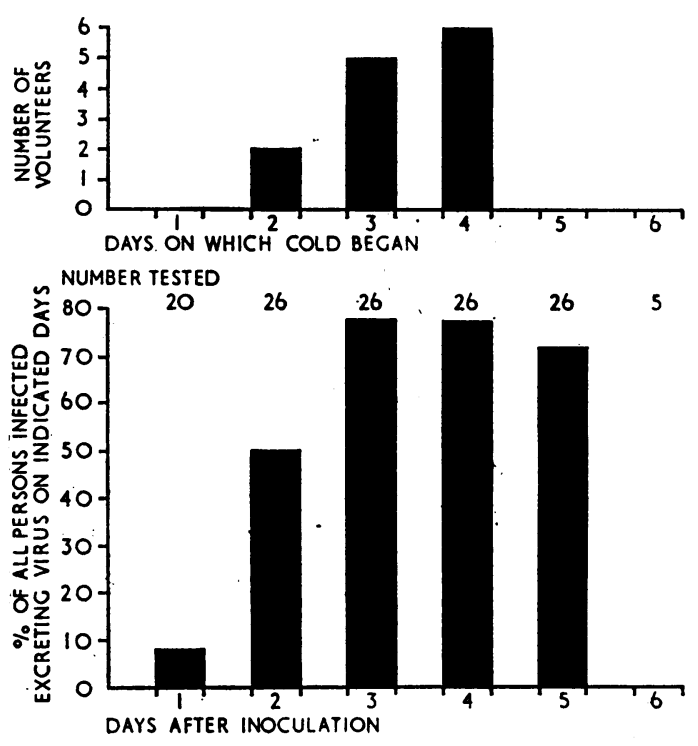

FIG. 2.- Time course of the onset of colds and the shedding of virus.

TABLE IV.-Relation Between Antibody Titre and the Response to Inoculation

\begin{tabular}{c|c|c|c|c|c}
$\begin{array}{c}\text { Titre of } \\
\text { Neutralizing } \\
\text { Antibody in } \\
\begin{array}{c}\text { Serum Before } \\
\text { Inoculation }\end{array}\end{array}$ & $\begin{array}{c}\text { No. of Volunteers in Indicated Category Who } \\
\text { Eirus }\end{array}$ & $\begin{array}{c}\text { Developed } \\
\text { Colds }\end{array}$ & $\begin{array}{c}\text { Developed } \\
\text { Rising } \\
\text { Antibody } \\
\text { Titres }\end{array}$ & Total \\
\hline 55 & 7 & 6 & 4 & 8 \\
$5-$ & 4 & 3 & 2 & 6 \\
$10-$ & 6 & 3 & 1 & 8 \\
$40-160$ & 1 & 1 & 0 & 4
\end{tabular}

\section{Clinical Pattern of Colds Produced}

The illnesses observed were all within the range of typical common colds. One was graded as severe (see Tyrrell, 1965), two as moderate, and the rest as mild. The main symptoms and signs are shown in Table $\mathrm{V}$, alongside similar figures for volunteers infected with the B814 virus and with rhinoviruses. It can be seen that the pattern of illness was, in general, similar to that produced by the B814 virus. The proportion of colds produced by these viruses was not significantly greater than that produced by rhinoviruses, but the mean incubation period was significantly longer. The duration of illness was shorter, significantly so when B814 colds were compared with DC colds. On the other hand, there were no significant differences between the two strains of avian-infectious-bronchitis-like viruses or between the two types of rhinoviruses in these measurements.

The means of the peak numbers of handkerchiefs used were higher in colds due to avian-infectious-bronchitis-like viruses than in those due to rhinoviruses. Though the differences were not formally significant, the median values also were higher in avian-infectious-bronchitis colds than in rhinovirus colds. This was mainly due to the fact that very few people with colds due to avian-infectious-bronchitis-like viruses ( 1 out of 47 ) used fewer than eight handkerchiefs, while over a quarter (43 out of 155) did so among those infected with rhinoviruses. This difference is highly significant statistically. However, two volunteers, one infected with $229-\mathrm{E}$ and one with B814, developed “streaming" colds, using over 100 paper handker- 
chiefs in one day. This was not seen after rhinovirus infections. Mucopurulent discharge was not seen at all after infection with 229-E, and, though this is unlikely to result solely by chance $(P=0.002)$, the real significance is obscure. Malaise was more common than in rhinovirus colds and cough was less common,

TABLE V.-Clinical Features of Colds Produced by Inoculating Four

\begin{tabular}{|c|c|c|c|c|}
\hline & \multicolumn{3}{|c|}{ ituses } & \\
\hline & \multicolumn{2}{|c|}{$\begin{array}{c}\text { Avian-Infectious- } \\
\text { Bronchitis-like }\end{array}$} & \multicolumn{2}{|c|}{ Rhinoviruses } \\
\hline & 229-E & B814* & $\begin{array}{c}\text { Type } 2 \\
\text { (HGP or PK) }\end{array}$ & DC* \\
\hline $\begin{array}{l}\text { No. of volunteers inocu- } \\
\text { lated } \\
\text { No. getting colds } \\
\text { Incubation period (days) }\end{array}$ & $13 \stackrel{26}{(50 \%)}$ & $\begin{array}{l}75 \\
34(45 \%)\end{array}$ & $\begin{array}{c}213 \\
78(37 \%)\end{array}$ & $\begin{array}{c}251 \\
77(31 \%)\end{array}$ \\
\hline 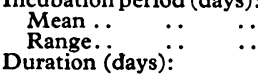 & $2-4$ & $2-5$ & $1-5^{2 \cdot 1}$ & $\underset{1-4}{2 \cdot 1}$ \\
\hline $\begin{array}{l}\text { Mean .. } \\
\text { Range.. } \\
\text { Maximum No. of hand- } \\
\text { kerchiefs used daily: }\end{array}$ & 3- 18 & $2-\stackrel{6}{17}$ & 3-19 & $\begin{array}{c}10 \\
2-26\end{array}$ \\
\hline 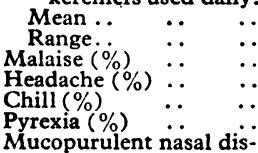 & $\begin{array}{l}23 \\
8-105 \\
46 \\
85 \\
31 \\
23\end{array}$ & $\begin{array}{l}21 \\
8-120 \\
47 \\
53 \\
18 \\
21\end{array}$ & $\begin{array}{l}14 \\
3-38 \\
28 \\
56 \\
28 \\
14\end{array}$ & $\begin{array}{l}18 \\
3-60 \\
25 \\
56 \\
15 \\
18\end{array}$ \\
\hline $\begin{array}{l}\text { charge }(\%) \\
\text { Sore throat }(\%) \\
\text { Cough }(\%) \\
\text { No. of volunteers with } \\
\text { colds of indicated } \\
\text { severity: }\end{array}$ & $\begin{array}{r}0 \\
54 \\
31\end{array}$ & $\begin{array}{l}62 \\
79 \\
44\end{array}$ & $\begin{array}{l}83 \\
87 \\
68\end{array}$ & $\begin{array}{l}80 \\
73 \\
56\end{array}$ \\
\hline $\begin{array}{lll}\text { Mild } . . & \ldots & \ldots \\
\text { Moderate } & \ldots & \ldots \\
\text { Severe } & \ldots & \ldots\end{array}$ & $\begin{array}{c}10(77 \%) \\
2(15 \%) \\
1(8 \%)\end{array}$ & $\begin{array}{c}24(71 \%) \\
7(20 \%) \\
3(9 \%)\end{array}$ & $\begin{array}{l}63(80 \%) \\
12(15 \%) \\
4(5 \%)\end{array}$ & $\begin{array}{l}36(47 \%) \\
28(36 \%) \\
13(17 \%)\end{array}$ \\
\hline
\end{tabular}

* Virus was administered only as nasal washings.

The statistical probability of some of the features of the colds due to 229-E virus $\mathrm{n}$ relation to colds due to other cold viruses are shown below.

\begin{tabular}{|c|c|c|}
\hline elation to colas due to & & \\
\hline (1) $t$-test on incubation periods & $\left\{\begin{array}{l}229-\mathrm{E}: \mathrm{B814} \\
229-\mathrm{E}: \mathrm{Rhino} \text { type } 2 \\
229-\mathrm{E}: \mathrm{DC} \\
\text { DC }: \text { Rhino type } 2\end{array}\right.$ & $\begin{array}{l}0.3>\mathbf{P}>0.25 \\
0.005>\mathbf{P}>0.001 \\
0.05>\mathbf{P}>0.025 \\
0.498>\mathbf{P}>0.495\end{array}$ \\
\hline (2) $t$-test on duration of colds & $\left\{\begin{array}{l}229-\mathrm{E}: \mathrm{B814} \\
229-\mathrm{E}: \mathrm{Rhino} \text { type } 2 \\
229-\mathrm{E}: \mathrm{DC} \\
\text { B814 }: \text { Rhino type } 2 \\
\text { B814 }: \text { DC } \\
\text { DC }: \text { Rhino type 2 }\end{array}\right.$ & $\begin{array}{l}0.15>\mathrm{P}>0.10 \\
0.10>\mathrm{P}>0.05 \\
0.20>\mathrm{P}>0.15 \\
0.10>\mathrm{P}>0.05 \\
0.01>\mathrm{P}>0.005 \\
0.95>\mathrm{P}>0.90\end{array}$ \\
\hline
\end{tabular}

but these and other symptoms and signs were not significantly different in any of the groups. Over one-fifth of volunteers infected with $229-\mathrm{E}$ had pyrexia, with an oral temperature between 99.2 and $100.4^{\circ} \mathrm{F}$. (37.3 and $38^{\circ}$ C.).

\section{Discussion}

The fact that of the six isolations of this virus made by Hamre and Procknow five were from patients with clinical colds and only one from a healthy subject suggested strongly that the virus caused colds. Our results supplement these observations and show that after serial passage in tissue culture the virus can multiply in human respiratory epithelium in vitro and in vivo and can cause the common cold syndrome. Infection and disease occurred even when the serum contained substantial titres of neutralizing antibody, a phenomenon that has also been found on administering parainfluenza and respiratory syncytial virus to volunteers (Reichelderfer et al., 1958; Tyrrell et al., 1959 ; Kravetz et al., 1961). The phenomenon might be due to lack of antibody in the nasal secretion of some persons with serum antibody, as appears to be the case with experimental infections with parainfluenza 1 virus (Smith et al., 1966), but the possibility was not investigated in our studies.

There was no evidence of lower respiratory tract infection in our volunteers, but since the virus appears to infect children, as judged by the occurrence of serum antibody, it is neverthe- less possible that the lower respiratory tract may be susceptible at that age and more serious disease may then be produced.

It is known that human sera often neutralize mouse hepatitis virus (Gledhill, personal communication). Funthermore, paired sera from $12 \%$ of Servicemen suffering from acute respiratory diseases have shown increasing antibody titres against mouse hepatitis virus (Hartley et al., 1964), and it is possible that this occurred because some viruses of the avian-infectious-bronchitislike group infect a significant proportion of such cases in the general population and induce the formation of antibody against the related virus. However, preliminary experiments have shown that our viruses are serologically distinct from avian infectious bronchitis and mouse hepatitis viruses on the basis of neutralization tests (Bradburne, Gledhill, and Berry, unpublished). There were no antibody rises against $229-\mathrm{E}$ in sera from volunteers who developed colds after inoculation with B814, and the isolates of McIntosh et al. (1967) were also serologically distinct from 229-E. It therefore seems likely that we are dealing with members of a group in which individual viruses are very species-specific and in which those strains that infect man belong to a number of distinct serotypes. However, further studies are being made on these and related problems, and the results will be reported later.

\section{Summary}

A virus, 229-E, which morphologically resembles avian infectious bronchitis virus has been passed serially four times in man. Colds were produced in 13 out of 26 inoculated volunteers. There was a significant association between the presence of virus in the nose and the development of colds. Seven of the 13 volunteers who developed colds showed rising titres of antibody against this virus. The colds showed significantly longer incubation periods than did colds due to rhinoviruses, but no longer than those of colds caused by the related virus B814. The colds were also shorter and were associated with more nasal discharge than rhinovirus colds, but many of the differences are not statistically significant.

Of 215 sera collected from children and adults in Britain in the past 10 years $29 \%$ contained neutralizing antibody.

It is concluded that the virus can cause colds and probably circulates to a significant extent in this country.

We would like to thank the volunteers for their co-operation; Miss E. M. Bullock for help with the clinical observations; Dr. D. Hamre for providing the virus and serum; Mr. S. Peto for advice on statistical problems ; and Mrs. P. K. Brown and Miss N. Frost for preparing the tissue cultures.

\section{REFERENCES}

Almeida, J. D., and Tyrrell, D. A. J. (1967). 7. gen. Virol., 1, 175. Andrewes, C. H. (1948). ₹. roy. Soc. Arts, 46, 200

Hamre, D., and Procknow, J. J. (1966). Proc. Soc. exp. Biol. (N.Y.), $121,190$.

Hartley, J. W., Rowe, W. P., Bloom, H. H., and Turner, H. C. (1964). Ibid., 115, 414.

Hayflick, L., and Moorhead, P. S. (1961). Exp. Cell. Res., 25, 585

Hoorn, B. (1966). Acta path. microbiol. scand., Suppl. No 183.

Kravetz, H. M., et al. (1961). F. Amer. med. Ass., 176, 657.

McIntosh, K., Dees, J. H., Becker, W. B., Kapikian, A. Z., and Chanock, R. M. (1967). Proc. nat. Acad. Sci.' (Wash.), 57, 933 .

Reichelderfer, T. E. et al. (1958). Science, 128, 779.

Smith, C. B., Purcell, R. H., Bellanti, J. A., and Chanock, R. M. (1966). New Engl. 7. Med., 275, 1145.

Tyrrell, D. A. J. (1965). Common Colds and Related Diseases. London.

and Almeida, J. D. (1967). Arch. ges. Virusforsch. In press.

二 and Blamire, C. J. (1967). Brit. F. exp. Path., 48, 217.

- and Bynoe, M. L. (1965). Brit. med. F., 1 , 1467.

Petersen, K. B., Sutton, R. N. P., and Pereira, M. S. (1959) 